\title{
Depression in Elderly
}

Pradhan S N*

Address: Associate Professor, Department of Psychiatry, Kathmandu Medical College Teaching Hospital, Kathmandu, Nepal

Email*Corresponding author: drsudar@yahoo.com

\section{Abstract}

Introduction: Depression is a serious public health problem in elderly and is often under diagnosed and under treated in this population. This study is conducted to identify the depression in old-age shelter home.

Material \& Method: The aim of the work was to study the social-demographic characteristics and the severity of Depression in old age shelter home. The study was carried out in the people who were living in the old-age shelter home. All individuals were rated using Beck Depression Inventory

Result: Total numbers of patients were 92 . Among all individuals $89.1 \%$ were found to be suffering from depression. The finding significantly shows that depression is increasing with the prolonged stay in sheltered home.

Conclusion: The prolonged stay in old-age sheltered home shows significant depression, which indicate need of acute interventional strategy to treat depression in such homes.

Key words: Old age, Depression, shelter home, Beck Depression Inventory

\section{INTRODUCTION}

Depression is a serious public health problem in elderly and is often under diagnosed and under treated in this population. ${ }^{1}$ Depression in the elderly has become a common social and economic problem in the world as the life expectancy has grown up. The World Health Organization expects that within 25 years people in all countries will have a life expectancy of over 50 years. Concurrently, people over 65 years of age will make up $10 \%$ of the world population. ${ }^{2}$

As the population grows older, clinicians will begin to see more elderly depressed patient. The Epidemiologic Catchments Area (ECA) study estimates that depressive symptoms are present in $15 \%$ of community residents over the age of 65 years. ${ }^{3}$ The prevalence of major depression in nursing home patients and other medical inpatient and out patients is higher, ranging from $9 \%$ to $42 \%{ }^{4}$

Prevalence of depression in elderly in Nepal is not known. This study was conducted in old-age shelter home in Kathmandu with aim to study the prevalence, socialdemographic characteristics and the severity of depression.

\section{MATERIAL \& METHOD}

The study was conducted at an old-age shelter home. The study was approved by the institute ethical review board. After Informed consent all individuals were rated using Beck Depression Inventory and socio-demographic data was collected using self-designed semi-structured form. Severely ill, not able to speak properly and individuals who did not consent were excluded. All the collected data was entered in the SPSS 13.0 for windows.

\section{RESULTS}

Total numbers of patients were 92. As shown in table 1 , maximum individuals were in the age group 81 years (39.1\%) closely followed by the age group 71-80 years $(33.7 \%)$ and $60-70$ years $(27.2 \%)$. Overall $89.1 \%$ of participants were found to be suffering from depression, in which moderate depression was $35.9 \%$, severe depression was found to be $29.3 \%$ and followed by mild depression $23.9 \%$

Table 1. The distribution between Beck Depression Inventory and age

\begin{tabular}{|c|c|c|c|c|c|}
\hline \multirow{2}{*}{ Age } & \multicolumn{4}{|c|}{$\overline{B D I}$} & \\
\hline & Normal & Mild & Moderate & Severe & Total \\
\hline $60-70 y r s$ & $\begin{array}{c}4 \\
16.0 \%\end{array}$ & $\begin{array}{c}3 \\
12.0 \%\end{array}$ & $\begin{array}{c}13 \\
52.0 \%\end{array}$ & $\begin{array}{c}5 \\
20.0 \%\end{array}$ & $\begin{array}{c}25 \\
100.0 \%\end{array}$ \\
\hline $71-80 y r s$ & $\begin{array}{c}3 \\
9.7 \%\end{array}$ & $\begin{array}{c}8 \\
25.8 \%\end{array}$ & $\begin{array}{c}8 \\
25.8 \%\end{array}$ & $\begin{array}{c}12 \\
38.7 \%\end{array}$ & $\begin{array}{c}31 \\
100.0 \%\end{array}$ \\
\hline$>81 \mathrm{yrs}$ & $\begin{array}{c}3 \\
8.3 \%\end{array}$ & $\begin{array}{c}11 \\
30.6 \%\end{array}$ & $\begin{array}{c}12 \\
33.3 \%\end{array}$ & $\begin{array}{c}10 \\
27.8 \%\end{array}$ & $\begin{array}{c}36 \\
100.0 \%\end{array}$ \\
\hline Total & $\begin{array}{c}10 \\
10.9 \%\end{array}$ & $\begin{array}{c}22 \\
23.9 \%\end{array}$ & $\begin{array}{c}33 \\
35.9 \%\end{array}$ & $\begin{array}{c}27 \\
29.3 \%\end{array}$ & $\begin{array}{c}92 \\
100.0 \%\end{array}$ \\
\hline
\end{tabular}

Severe depression was highest among individuals between age of $71-80$ years $(38.7 \%)$, followed by individuals more than 81 years $(27.8 \%)$ and only $20 \%$ in individuals between age $60-70$ years. 
Table 2. The relation between the depression and long term stay in old age sheltered home

\begin{tabular}{|c|c|c|c|c|c|}
\hline \multirow[b]{2}{*}{ BDI } & \multicolumn{4}{|c|}{ Duration of staying } & \multirow[b]{2}{*}{ Total } \\
\hline & $\begin{array}{c}\text { Staying }<6 \\
\text { months }\end{array}$ & $\begin{array}{l}\text { Staying } \\
\text { for 2yrs }\end{array}$ & \begin{tabular}{|c|}
$\begin{array}{c}\text { Staying for } \\
\text { 5yrs }\end{array}$ \\
\end{tabular} & $\begin{array}{c}\text { Staying } \\
>5 \text { yyrs }\end{array}$ & \\
\hline Normal & $\begin{array}{c}1 \\
(10 \%) \\
\end{array}$ & $\begin{array}{c}2 \\
(20 \%)\end{array}$ & $\begin{array}{c}3 \\
(30 \%) \\
\end{array}$ & $\begin{array}{c}4 \\
(40 \%)\end{array}$ & $\begin{array}{c}10 \\
(100 \%)\end{array}$ \\
\hline Mild & $\begin{array}{c}4 \\
(18.2 \%)\end{array}$ & $\begin{array}{c}2 \\
(9.1 \%)\end{array}$ & $\begin{array}{c}3 \\
(13.6 \%)\end{array}$ & $\begin{array}{c}13 \\
(59.1 \%)\end{array}$ & $\begin{array}{c}22 \\
(100 \%)\end{array}$ \\
\hline Moderate & $\begin{array}{c}2 \\
(6.1 \%) \\
\end{array}$ & $\begin{array}{c}9 \\
(27.3 \%)\end{array}$ & $\begin{array}{c}6 \\
(18.2 \%)\end{array}$ & $\begin{array}{c}16 \\
(48.5 \%)\end{array}$ & $\begin{array}{c}33 \\
(100 \%)\end{array}$ \\
\hline Severe & $\begin{array}{c}3 \\
(11.1 \%)\end{array}$ & $\begin{array}{c}7 \\
(25.9 \%)\end{array}$ & $\begin{array}{c}4 \\
(14.8 \%)\end{array}$ & $\begin{array}{c}13 \\
(48.1 \%)\end{array}$ & $\begin{array}{c}27 \\
(100 \%)\end{array}$ \\
\hline Total & $\begin{array}{c}10 \\
(10.9 \%)\end{array}$ & $\begin{array}{c}20 \\
(21.7 \%)\end{array}$ & $\begin{array}{c}16 \\
(17.4 \%)\end{array}$ & $\begin{array}{c}46 \\
(50 \%)\end{array}$ & $\begin{array}{c}92 \\
(100 \%)\end{array}$ \\
\hline
\end{tabular}

There was no correlation between length of stay and depression. The caste distribution shows the majority were from Brahmins followed by Chhetri, which depicts the country-wise distribution in Nepal.

Table 3. The caste distribution in elderly individuals.

\begin{tabular}{|c|c|c|c|c|c|c|c|}
\hline \multirow{2}{*}{ Age } & \multicolumn{6}{|c|}{ Caste } & \\
\hline & Brahmin & Chhetri & Newar & Tamang & $\begin{array}{c}\text { Rai/ } \\
\text { limbu }\end{array}$ & Other & Total \\
\hline $\begin{array}{c}60- \\
70 y r s\end{array}$ & $\begin{array}{c}8 \\
(32 \%)\end{array}$ & $\begin{array}{c}6 \\
(24 \%)\end{array}$ & $\begin{array}{c}5 \\
(20 \%)\end{array}$ & $\begin{array}{c}0 \\
(0 \%)\end{array}$ & $\begin{array}{c}2 \\
(8 \%)\end{array}$ & $\begin{array}{c}4 \\
(16 \%)\end{array}$ & $\begin{array}{c}25 \\
(100 \%)\end{array}$ \\
\hline $\begin{array}{c}71- \\
80 y r s\end{array}$ & $\begin{array}{c}12 \\
(38.7 \%\end{array}$ & $\begin{array}{c}7 \\
(22.6 \%)\end{array}$ & $\begin{array}{c}6 \\
(19.4 \%)\end{array}$ & $\begin{array}{c}3 \\
(9.6 \%)\end{array}$ & $\begin{array}{c}0 \\
(0 \%)\end{array}$ & $\begin{array}{c}3 \\
(9.6 \%)\end{array}$ & $\begin{array}{c}31 \\
(100 \%)\end{array}$ \\
\hline$>81 \mathrm{yrs}$ & $\begin{array}{c}16 \\
(44.4 \%) \\
\end{array}$ & $\begin{array}{c}12 \\
(33.3)\end{array}$ & \begin{tabular}{|c|}
4 \\
$(11.1 \%)$
\end{tabular} & \begin{tabular}{|c|}
0 \\
$(0 \%)$
\end{tabular} & $\begin{array}{c}1 \\
2.7 \%)\end{array}$ & \begin{tabular}{|c|}
3 \\
$(8.3 \%)$
\end{tabular} & $\begin{array}{c}36 \\
(100 \%)\end{array}$ \\
\hline Total & $\begin{array}{c}36 \\
(37.5 \%\end{array}$ & $\begin{array}{c}25 \\
(27.2 \%)\end{array}$ & $\begin{array}{c}15 \\
(163 \%)\end{array}$ & $\begin{array}{c}3 \\
(3.3 \%)\end{array}$ & $\begin{array}{c}3 \\
(3.3 \%)\end{array}$ & $\begin{array}{c}10 \\
(10.9 \%)\end{array}$ & $\begin{array}{c}92 \\
(100 \%)\end{array}$ \\
\hline
\end{tabular}

Table 4. Sex distribution of elderly people living in government old-age sheltered home

\begin{tabular}{|c|c|c|c|}
\hline \multirow{2}{*}{ Age } & \multicolumn{2}{|c|}{ Sex } & \multirow{2}{*}{ Total } \\
\cline { 2 - 3 } & Male & Female & \\
\hline $\mathbf{6 0 - 7 0 y r s}$ & $7(28 \%)$ & $18(72 \%)$ & $25(100 \%)$ \\
\hline $\mathbf{7 1 - 8 0 y r s}$ & $11(35.5 \%)$ & $20(64.5 \%)$ & $31(100 \%)$ \\
\hline$>\mathbf{8 1 y r s}$ & $\mathbf{1 6}(44.4 \%)$ & $20(55.6 \%)$ & $36(100 \%)$ \\
\hline Total & $\mathbf{3 4 ( 3 6 . 9 \% )}$ & $\mathbf{5 8 ( 6 3 . 1} \%)$ & $\mathbf{9 2 1 0 0 . 0} \%$ \\
\hline
\end{tabular}

Table 4 shows sex distribution of elderly people living in government old-age sheltered home.

\section{DISCUSSION}

The present study shows that most $(89.1 \%)$ of the individuals at the elder shelter home are suffering from depression and only very few $(10.9 \%)$ are depression free. There is no difference in duration of the stay at the elder shelter home and depression. This means most of the individuals were probably already depressed at the time of entering the shelter and they continued to be depressed throughout their stay. It also highlights the lack of timely diagnosis and treatment of mental health problems in this facility.

The rate of depression in our study is quiet high and this is probably due to our sample which is from a shelter home.
Elders moving to shelter home in Nepal are often neglected by family, economically deprived, have multiple medical problems and suffer poor care and isolation at the shelter, all these factors could contribute to increased rate of depression in elderly. ${ }^{5-7}$

In this study none of the elderly were diagnosed or treated for depression. This is probably due to lack of awareness of this problem among general public as well as in medical community. Elderly patients do not complain of depressive symptoms rather somatic symptoms may predominate. The consequence is that these patients are under treated and their depression is unrecognized. ${ }^{8}$

This study has shown that depression is a major mental health problem in elderly in Nepal. The very high number of depression seen in this study may be due to sample bias as discussed above. If we assume that the general population suffered half the rate of depression seen in this study that means almost half of the elderly in Nepal are suffering from depression. As we are going through rapid urbanization and people are living longer this problem will get bigger. We all should be aware of this and necessary action should be initiated from concerned professionals and authorities.

\section{CONCLUSION}

This is a small study that was limited to elder shelter home but it does highlight that significant number of elders in Nepal suffer from depression. Awareness programs should be initialed to make public and medical community conscious of this problem. Further larger controlled studies should be conducted to understand this problem further and develop needed intervention strategies.

\section{Reference}

1.Salzmann C. Update on the somatic treatment of depression in older adult: psychopharmacology and ECT. J . Geriatr Psychiatry 1997; 30: 259-270.

2.World Health Organization. Fifty facts from The world Report 1998. Available at www.who.int/whr/1998/ factes.html. Accessed March 5.2001.

3.NIH Consensus Development Panel on Depression in late life. Diagnosis and treatment of Depression in late life. JAMA 1992; 268: 1018-1024.

4.Nelson JC. Treatment of major depression in the elderly. In: Nelson JC, ed Geriatric Psycho pharmacology. New York. NY: Marcel Dekker, 1998: 61-97.

5.Wilson KC, Chen R, Taylor S, Mc Cracken CF, Copeland JR. Socoieconomic deprivation and the prevalence and prediction of depression in older community residents. Br. J Psychaitry 1999; 175: 549-53.

6.West CG, Reed DM, Gildengorin GL. Can money buy happiness? Depressive symptoms are an affluent older population. J. Am Geriatr Soc 1998; 46: 49-57.

7.Armer J, Elderly relocation to a congregate setting: factors influencing adjustment. Issues Ment Health Nurs $1993 ; 14: 157-72$.

8.Kennedy GJ. The geriatric syndrome of late-life depression. Psychiatr Serv 1995Jan; 46(1):43-8. 